\title{
Lessons We Can Learn
}

\author{
Address by LAWRENCE K. ROOS, President, Federal Reserve Bank of St. Louis, before the St. Louis Council \\ on World Affairs, St. Louis, Missouri, October 7, 1981
}

\begin{abstract}
A is now the most serious problem facing most nations thronghout the world. For those individuals who have failed to correctly anticipate the course of inflation, the result has been capricious - and often disheartening - wealth losses. Even for those who have attempted to anticipate its coming, inflation has produced significant changes in economic behavior: saving and investment have declined substantially, productivity has fallen, and financial markets have experienced increased instability and uncertainty. The general result has been lower standards of living for the citizens of this nation and for much of the rest of the world.
\end{abstract}

Today I would like to discuss certain aspects of the worldwide rise in inflation that has occurred over the past decade and a half. In particular, I would like to share some personal observations and impressions that I gleaned during a recent visit to the United Kingdom, Switzerland and West Germany. These observations concern the different social and political forces affecting the conduct of monetary policy in different nations.

There are three basic propositions that I wish to stress in my discussion:

First: that persistent inflation whenever it occurs is a monetary phenomenon; it results simply from excessive growth of the money supply,
Second: that central banks are the creators of money and, consequently, in spite of monetary control techniques that differ between nations, they are capable of reducing, even eliminating, inflation if they so choose,

Third: that when central banks have chosen not to contain the growth of money and inflation, this choice has usually resulted from pressures exerted by social and political forces that do not especially desire price stability.

The first two propositions are most easily demonstrated by simply comparing the monetary expansions and inflation experiences of West Gemany, Switzerland, the United Kingdom and the United States over the past 15 years.

As mature, developed and open economies, each of these nations has been similarly affected by a host of nonmonetary factors, such as the vagaries of weather, OPEC, and the general expansion of government activities. Yet, in spite of the commonality of these influences on their respective economies, there are discemibly uncommon differences between the four nations in the manner in which they have conducted monetary policy and in the associated inflation they have experienced.

During the early $1960 \mathrm{~s}$, Switzerland had the highest rate of money growth (over 9 percent per year) 
and, consequently, the highest rate of inflation (about 5 percent per year). At that time, the United States, in contrast, had the lowest rate of money growth (about 3 percent per year) and, again, not surprising$1 \mathrm{y}$, the lowest inflation rate (less than 2 percent per year). Rates of money growth and inflation in the United Kingdom and West Germany fell somewhere between the United States and Switzerland. [See table 1.]

What a difference the past 15 years have made! Since the mid-1960s, money growth in the United Kingdom and the United States has steadily accelerated. Over the past five years, U.S. monetary expansion was more than double what it was during the early 1960s. Money growth in the United Kingdom more than tripled its pre-1965 growth rate.

The patterns of Swiss and West German money growth over the past 15 years stand in sharp contrast to those of the United States and the United Kingdom. The Swiss rate of monetary increase has declined sharply since the mid-1960s. West German money growth has shown a mixed pattern - sometimes sharply decelerating, sometimes sharply accelerating. However, over the past five years it was less than its rate of growth in the early 1960 s.

As a result of these divergent pattems, while inflation has averaged more than 13 percent per year in the United Kingdom and over 7 percent per year in the U.S. for the past five years, Germany has experienced only a 4 percent average annial inflation, and inflation in Switzerland averaged a miniscule 2 percent per year.

Of course, over short periods, nommonetary factors can also affect the rate of inflation. For example, as a result of OPEC, rates of inflation increased dramatically in all four nations from 1973 to 1975. After 1975 , however, the fundamental relationship between changes in the growth of money and changes in the rate of inflation was reasserted. Inflation declined in West Germany and Switzerland and increased in the United Kingdom and the United States, reflecting the different patterns of monetary expansion in these countries.

This brief description of the interaction of money growth and inflation demonstrates one point quite clearly. Because West Germany and Switzerland have maintained fairly tight control over the direction of growth of their money stocks, they have achieved relatively low average rates of inflation. This, unfortunately, was not the case in the United Kingdom and the United States. The important question to be answered is "Why the differences?"

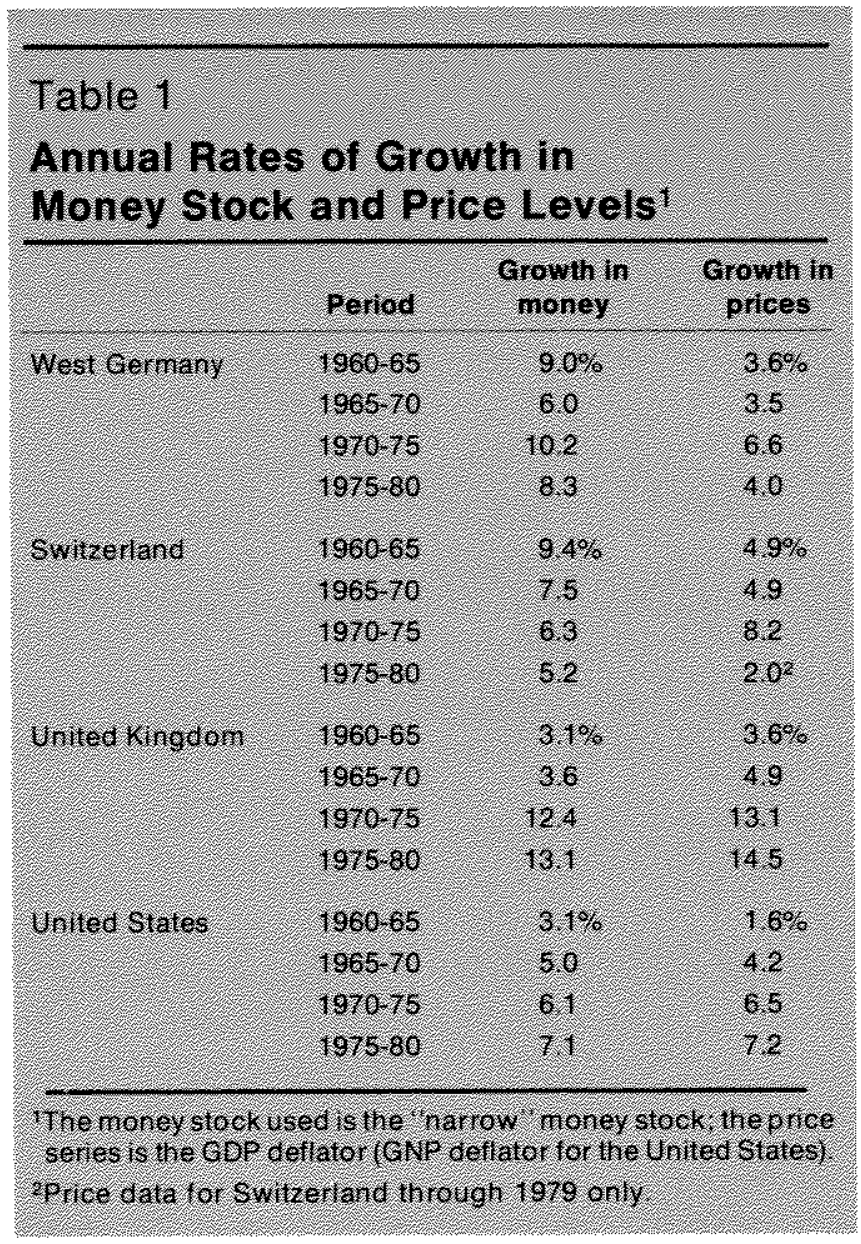

I believe that the answer can be found in social and political pressures that arise in response to temporary economic "discomforts" which affect certain segments of the economy in times of monetary restraint. These discomforts, though painful, are a necessary part of the process essential to winding down inflation. They arise in the following ways.

Monetary restraint designed to reduce inflation usually produces some initial, but temporary, ad. verse impacts on employment and production. Higher unemployment and slow economic growth, however temporary, inevitably generate sentiment to abandon policies of restraint.

For monetary restraint to prevail, policymakers must be prepared to permit interest rates to fuctuate freely in accordance with market influences. Unanticipated fluctuations in interest rates have adverse effects on interest-rate-sensitive sectors of society such as the housing and financial industries. They may also produce movements in foreign exchange rates which can have a disturbing effect on export and import industries. These groups can be expected 
to react to their discomfort by exerting political pressure upon monetary policymakers to retreat from restraint.

Finally, stable monetary control subjects the government to increased financial discipline. It forces govemment to finance its expenditures through higher taxes or through borrowing directly from the public. Either way, the expenditures become subject to greater public scrutiny. And such scrutiny and consequent discipline may not be politically acceptable to those in govermmert.

These social and political forces, arising as consequences of monetary restraint, place enomous pressure on monetary policymakers to abandon attempts to control and reduce inflation. If, through the political process, temporary economic protection of certain sectors of society takes precedence over price stability, the central bank, irrespective of its independence, will find it increasingly difficult to maintain strict monetary control.

How these social and political pressures influence the conduct of monetary policy is dramatically illustrated in the cases of the United Kingdom, Switzerland and Germany.

The United Kingdom, since World War I, has faced changes in worldwide economic and political conditions that have rendered some of its economic sectors inefficient. Instead of permitting these industries to decline and new ones to arise in their place - a process that would have entailed a temporary decline in living standards during the transition - the political decision was made to protect the affected industries. Govemment expenditures and govemment deficits grew; their costs burgeoned. Ultimately, when all else falled, the government itself entered directly into the business of producing goods and services via nationalization of specific industries.

Concurrently, a constituency evolved whose primary goal was to maintain high rates of employment at all times and to maintain the existing standard of living despite declining demand and productivity. Over time this constituency grew in political strength and was able to force monetary policymakers to accelerate money growth. This expansion in money growth, and the subsequent higher inflation, did not result from faulty techniques or perverse intentions on the part of the Bank of England. It occurred simply because the central bank responded to ever-increasing pressures from the public and private sectors that benefited from an inflionary enviromment.
In Switerland, the central bank faces significantly different kinds of political and social pressures. For decades, Switzerland has been willing to tolerate the decline of its major industries - agriculture and watchmaking - as changes occurred in world economic conditions. For example, at the start of the 1970s, Swiss watchmakers produced about 80 percent of all watches made. Currently, they produce only about 30 percent and this share is continuing to decline, as watchmaking has shifted to the Orient. The Swiss, in turn, pemitted resonrces to be reallocated into manufacturing and financial service industries, and were willing to endure higher unemployment in the process.

Why do the Swiss place greater emphasis on price stability than on employment stability? First, much of the Swiss labor force consists of so-called "guest workers" who are citizens of neighboring nations. Since temporary rises in unemployment fall more heavily on "guest workers," the political impact of unemployment on the Swiss electorate is lessened. Furthermore, one of the most important Swiss indus tries - the providing of financial services to the rest of the world - owes its very existence to the stability of the value of the Swiss franc. Because Swiss manufacturing relies almost solely on imported raw materials, and to some extent, imported labor, shortterm fluctuations in exchange rates have little net effect on Switzerland's important export industries. Finally, the Swiss government sector is relatively small and is engaged in virtually no income maintenance endeavors.

Under these circumstances, it is easy to see that, although there are a few sectors of the Swiss economy that would benefit from protection from the side effects of monetary restraint, the Swiss proinflation constituency is relatively small. As a result, the central bank is free to control monetary growth irrespective of short-term fluctuations in interest rates, exchange rates or unemployment rates.

West Germany lies somewhere between the United Kingdom and Switzerland in terms of factors impacting its conduct of monetary policy. Although, like Switzerland, it is a society that is dommated by the private sector, it resembles the United Kingdom in that it has numerous income maintenance programs and a large government sector. Also, like the United Kingdom, Germany has industries that are highly dependent on exports and, therefore, benefits from a lower foreign-exchange value of its currency. There are also short-run pressures to maintain low interest rates to favor vamious interest-sensitive industries. 
On the other hand, there are important factors in Germany which contribute to the viability of antiinflationary policies. The Bundesbank is legally independent of the federal government; the prevalence of "gnest workers" mitigates somewhat the concern over higher unemployment, and Germany has not yet been faced with the problem of declining industries. Most important of all, German citizens remember, either first or second hand, the ravages of the hyperinflation of the early 1920 s. They are still willing to suffer some temporary economic dislocations to avoid a repetition of the tragedy of hyperinflation.

Thus, while there are growing demands in West Gemany for income redistribution and, therefore, for income maintenance policies, the overwhelming priority is still to prevent an acceleration in inflation. As a result, the Bundesbank is free to pursue monetary restraint and to disregard most of the transitional problems that may occur as a result.

What lessons can we in the United States leam from these comparisons? Can they be applied to our conduct of monetary policy?

First, the Swiss and West German experiences make it clear that monetary policy can be used to control and reduce the rate of inflation. The Swiss and West German experiences provide good examples of this.

More importantly, however, experience demonstrates that monetary control is possible only if the central bank has a clear mandate to control inflation. A political and social consensus that price stability is the primary priority and responsibility of the central bank must prevail.

Third, it is obvious that the larger the government sector becomes relative to the private sector, the greater are the pro-inflation pressures on monetary policymakers. This is not because governments consciously desire inflation. Rather, it is because inflation, especially if it is unanticipated, makes it easier for the government sector to expand its control over national resources and provide politically desirable services. The United Kingdom and the United States are good examples of this phenomenon.
Perhaps the biggest problem that monetary policymakers face today in the United States is that the constituency for sectoral protection, the pro-inflation constituency, is growing. More and more groups, through their elected representatives, have been demanding protection from adverse market pressures and interest rate fluctuations. We protect the unemployed, the elderly and the minorities. We protect farmers, the housing industry, the automobile industry, the thrift industry and the bond dealers. The list can and, unless we do something about it, will go on and on.

Achievement of price level stability implies that all sectors of the economy must be subject to market forces. It is the fear of these market forces that produces powerful political pressures for protection. against inflation rather than elimination of inflation. Once this protection syndrome becomes embedded in society, the retum to price stability becomes increasingly difficult.

We in the United States are presently at the crossroads. As our inflation-protected constituencies continue to grow, as they encompass an even greater portion of our society, there will be increased pressures on the monetary authorities to abandon the ir attempts to combat inflation. The events of the past several weeks - the cries of anguish that interest rates must be forced down immediately and at any cost - are a reflection of such political pressures in action.

In a democratic society, even the titularly "independent" central bank cannot remain immune from political pressures. As Arthur Burns has noted, the anguish of central banking arises not from its inability to control money growth, but rather from the diffoulties that central bankers have in overcoming the political pressures associated with monetary restraint.

If we pull back now from our current policy of monetary restraint, we will, once again, have acted to prolong ind, perhaps, to institutionalize inflation in this nation. We must now choose between longterm benefits for all or short-tem gains for a few. What will our decision be?

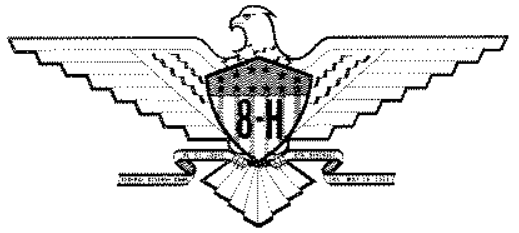

